\title{
After Retrotopia? The future of organizing and the thought of Zygmunt Bauman
}

\author{
Jerzy Kociatkiewicz \\ The University of Sheffield \\ kociak@kociak.org \\ Monika Kostera \\ Jagiellonian University \\ monika@kostera.pl
}

\begin{abstract}
The main body of work of Zygmunt Bauman concerns his home discipline of sociology, but his insights have been influential also in the field of organization studies. In this text, we provide an overview of the extent of this influence, providing some additional context for positioning the other contributions to this special section. Afterwards, we explore in more detail two notions central for Bauman's late thought: that of liquidity and retrotopia. The former constitutes the root metaphor for theorizing the current global predicament. In this text, we analyse how two modes of interpreting it, using the assumptions behind Kurt Lewin's CATS model and the alchemical tradition underpinning Carl Gustav Jung's conception of archetypes respectively, can help us theorize the alternative modes of organizing and managing encountered in a study of contemporary alternative organizations.
\end{abstract}

These insights form the starting point for our second goal: to explore Bauman's notion of retrotopia as a potentially fruitful starting point for discussing both the deficiencies of current visions of our future society, and the possibilities and vicissitudes of developing new forms of organizing and managing. Such new forms, both as practice and as theoretical constructs, are urgently needed if we are to face the numerous, and potentially catastrophic global challenges facing our society today.

Keywords: Zygmunt Bauman, liquid modernity, liquidity, retrotopia. alternative organizations

\section{Zygmunt Bauman and organization studies}

This special section of the Scandinavian Journal of Management considers the legacy Zygmunt Bauman has left for organization studies. As one of the greatest humanists of our times, best he is best known as a sociologist and public intellectual, and his work has inspired work of many organizational theorists, including our own. But it was our privilege to know him not only through his writing and lectures, but also to talk with him, drink wine with him, laugh, and write with him. He was a kind man, radiating genuine warmth and compassion. He had a profound respect for life. Also, he was a genius. His work will continue to be read and remembered in 50, in 100 years' time from now. Knowing him was getting to touch eternity. And yet he was always refreshingly modest, never stooped to any form of self-promotion or sense of entitlement. Whenever he was sad, if sufficed to tell him of a young student or someone he'd never even met who had enjoyed something he wrote. He would lighten up, 
as if happily surprised; it never ceased to amaze him that people would take his work to heart. If he had an ambition, it was to become part of people's lives and ideas. He was a thinker but most of all, a teacher, through and through. He showed a way to write, think and live, and consequently chose humanity over fame, tenderness over façade, suffering over success.

The departure point for this reflection is Bauman's last book, Retrotopia (2017). Four eminent contemporary organization scholars present a reflective view on the resonances the book brings into our discipline, regarded by all authors as a vital part of social sciences.

Bauman's work has been influential many fields of the humanities and social sciences, which necessarily includes organization studies. While he himself rarely wrote explicitly on the topic of management studies (the notable exception being a book we co-wrote with him and Irena Bauman: Bauman et al., 2015), significant strands of Bauman's thought taken up by organization theorists refer to his early writings on class (e.g. Jermier and Clegg, 1994), critiques of rationality (e.g. Burrell, 1995) and bureaucracy (e.g. Clegg, 2006), ideas of ethics (e.g. ten Bos, 1997; Gabriel, 1999a; Kelemen and Peltonen, 2001), and coming to terms with liquid modernity (e.g. Morgan and Ramanathan, 2009). Issues ranging from ecology and climate change (Skoglund, 2015) through values and strategies relevant for the sustainability of an (organized) future (Kornberger, 2013), to consumer management (Izak, 2015) and management figured as the transcending of time (Griesbach and Grand, 2013) have all been analysed in relation to Baumanian reflection. Yet while references to Bauman's texts abound in organization studies, few published works use his insights in a substantial manner. There are a few exceptions, such as an essay by Stewart Clegg (forthcoming) dedicated in its entirety to Bauman's influence in social sciences, an article by Mihaela Kelemen and Tuomo Peltonen (2001) discussing Foucauldian and Baumanian ethics and morality as alternatives to "business ethics" and a book edited by ourselves (Kociatkiewicz and Kostera, 2014a), focusing on Baumanian themes in organization theory.

The first of the three (Clegg, forthcoming) presents the development of Zygmunt Bauman's thought alongside the key events in his and his wife's life that had an impact on the way he approached problems of society.
Clegg takes up the reception of these ideas among some organization theorists and accounts for the potential of themes and concepts such as solid and liquid modernity. He goes on to depict the broader social and political context of the modern world and how an ongoing liquefaction imposes a mode of organizing that actively destroys social institutions. Leadership became a proxy for personal enrichment and management a purely financial exercise, without the past obligation to produce. Organizations become liquidated, argues Clegg, becoming something of an oxymoron, powerful and global yet unwilling and unable to take up any commitments beyond financial consideration. What used to be regarded as a pathology, an instance of dissolution, has now become the new norm. This state of affairs breeds resentment but the present social system cannot offer a solution from within itself. Instead, humanity seems to have set out to turn back time, and so do organization studies. They have become, Clegg asserts, unwilling to engage with social theories, focussing instead on the retrotopian project of seeing more and more perfected professionalization, specialization and retrieving of old structures. Instead of looking for new ideas, with the help of social theory, the discipline insists on gazing back at itself or, rather, at its own aspirational image in a bygone time that never really materialized.

Mihaela Kelemen and Tuomo Peltonen (2001) consider business ethics in the light of ideas of two authors: these of Michel Foucault and Zygmunt Bauman. They see important differences but also similarities between the approach of both authors. They understand ethics and morality differently: for Bauman ethics is normative, while morality, descriptive, and Foucault regards ethics as instrinsic while morality, for him, is extrinsic. However, they both believe that ethics and morality are two distinct phenomena. Kelemen and Peltonen do not agree with it, upholding, instead, that it is the relationship between humans and management that needs to be in focus, not between the ethical/moral system and the self at work. They argue that organizations have been changing during the last decades, thus the need to reflect on the ethical implications of new, postFordist organizational realities. In this context, there is an interesting convergence between the views of Bauman and Foucault, in their concern with the effects of modernization on society. The keystone in Zygmunt Bauman's perspective is the imperative of being for 
the Other, regarded as the primary moral impulse. Structures and rules, such a bureaucracy, support but also help human beings to escape from the moral impulse. Management has a tendency to evade engaging with the Otherand thus becomes concentrated on resources and effectiveness, adopting instrumental rationality as its ethical mode, one which is detached from the primary moral impulse. Bauman's approach, founded on Emmanuel Lévinas (1999), problematizes modernity as unable to follow the moral impulse, which is unconditional and rooted in human relationships and subjectivities. Here Kelemen and Peltonen contrapose the ideas of Michel Foucault, who posits ethics as a structuring process, like domination and discipline, directed at the primary forces of sociality. For him, the human being cannot depend on primary impulses, as no such impulse is free from influences of control. Instead, Foucault proposes ethics of curiosity, of transcending one's own presumptions and stepping into the reality of others. Kelemen and Peltonen propose to connect ideas of Bauman and Foucault to shed light on issues of management in contemporary organizations: to look beyond metarules and release moral instincts, whether they are driven by relationships or curiosity, and whether to be found in the subject or in sociality. However, in order to accomplish this, ethics must be detached from absolutist and rationalist discourses:

The main task of business ethics could now be to restore and revitalize that ordinary art of life, not to confuse it with the purification programs of bureaucracy and modernism (ibid., p. 164).

Finally, our own edited book (Kociatkiewicz and Kostera, 2014a) on the influence of Zygmunt Bauman's ideas on organization and management studies aims to comprehensively chart his writings' impact on organization theory until now. The chapters, written by authors from different countries, coming from a range of theoretical schools, all regard Zygmunt Bauman a major inspiration in their work and present current organization and management ideas, using a wide range of his ideas, ranging from the reflections on solid modernity in Modernity and the Holocaust, via the liquid modern times to the Interregnum. Whereas Zygmunt Bauman himself claimed that there is no such thing as the "Baumanian school" in sociology (Kuczyński, 2011), the book presents something of a Baumanian window to the world, one allowing to approach the social world with sociological imagination
(Mills, 1959), and, at the same time, in an engaged and compassionate way. We identified the three key themes that are defining of Bauman's writings: the dynamics of modernity, systemic social change, and sociological compassion.

The first theme concerns Bauman's reflections on the evolution of late modernity, from the system based on solid structures of the first half of the 20th century, to the liquid, fragmented society of today. Solid modernity developed technologies and institutions which made communal action particularly effective and moved agency into impersonal rules and structures. Liquid modernity is a period of increasing dissolution and dissipation of not only structures and institutions, but all expressions of organized sociality, leading up to the moment of evident collapse of known social mechanisms, which Bauman labels the interregnum (a concept we will return to later in this text). In the latter phases of modernity, sensemaking, individual as collective, has become precarious. The erosion of institutions and the failure of sensemaking give birth to a number of deleterious effects, in particular the inability to solve macro problems on a macro level and the resulting search for solutions in the past - a strategy which cannot work, as it is impossible to turn back time. This is the main argument of Retrotopia (Bauman, 2017), more about which in a moment.

The second leitmotif of Bauman's work is that of the possibility of systemic social change. He stressed both the societal, systemic mechanisms, and of the potential of social and communal consciousness and agency. This potential has in the present times, paradoxically, taken the appearance of insufficiency and powerlessness while, simultaneously, revealing itself as the only possible solutions to our most significant social problems. The signs of socioecological catastrophe are visible for all who care to look, even if interpretations of its causes and exact nature may differ. Yet social institutions are created and reinforced by social effort, and thus require social effort to change. To the question whether we can remedy our dire situation, Bauman answers: "will never know unless we try: again and again, and ever harder" (2013a, p. 96).

The third major theme in Bauman's writings is concerned with the fate and wellbeing of humanity. Echoing C. Wright Mill's (1959) notion of sociological imagination, we propose (Kociatkiewicz and Kostera, 
2014b) to call it sociological compassion. As already mentioned, Zygmunt Bauman (1993) builds on the philosophy of Lévinas, and regards the responsibility to the Other as preceding all other manifestations of human sociality. The empathic imagination (Bauman, 2011) equips us, social actors as well as theorists of the social, with a power to discern, understand and act upon moral impulses, implied in human nature. It is a strong and profoundly human, and therefore viable, alternative to a view of social problems focusing solely on the economic, technical and structural. This perspective helps us transcend the limitations imposed by narrow rationalities and move our collective being out of the trajectories of predictability - and defeat.

In one of his oft-repeated anecdotes, Bauman described the sage advice he received from his sociological mentor, Stanisław Ossowski. He was cautioned to avoid making predictions and, if forced to do so, to never, ever try to predict the future. The advice is certainly sound, and the predictive record of social sciences is almost universally abysmal. And yet this very future, unknowable and uncontrollable remains a constant preoccupation of human beings, including social and organizational scientists. Bauman himself often discussed (though never, to our knowledge, tried to predict) the future, possibilities and hopes from his relatively early writings on socialism $(1967 / 2011)$ to his last book, Retrotopia (2017). The latter text, building upon earlier writings as well as a reflection of the themes dominant in contemporary social and political imagination, informs all four of the articles included in this special section, and offers an appropriate starting point for considering the legacy Zygmunt Bauman has left to organization studies. Consequently, we will now present a contextualized reading of Retrotopia, then our own attempt to follow up the directions of sociological thought which the book offers, and, finally, we briefly depict the contributions to the special issue against that background.

\section{Towards retrotopia...}

Our times are unlike those of solid modernity. Liquidity has undermined and eroded social institutions. We have reached a point in time, where nothing seems to be working: the old system has ceased to be effective, but no replacements are in sight (Streeck, 2016). Zygmunt
Bauman (2012) uses Antonio Gramsci's metaphor of the interregnum to depict these times:

The old is dying and the new cannot be born. In this interregnum a great variety of morbid symptoms can appear. (Gramsci, 1971, p. 276)

To Bauman, the current interregnum is

a time-span of yet unknown length, stretching between a social setting which has run its course and another, as yet under-defined and most certainly under-determined, which we expect or suspect to replace it (Zygmunt Bauman, in Bauman, Bauman, Kociatkiewicz and Kostera, 2016, p. 17).

Social institutions, the shared, internalized and taken for granted patterns and assumptions, including the knowledge of what reality is, enable joint action on societal and organizational scale (Berger and Luckmann, 1966/1991). Their importance is fundamental because they make certainty possible, by making sure

that each [social actor] will be able to predict the other's actions. Concomitantly, the interaction of both becomes predictable. [...] Each action of one is no longer a source of astonishment and potential danger to the other (p. 57).

While capitalist social order has always relied on crises and disruptions for self-regulation, in liquid modernity the fragmentation and erosion of institutions has been taken much further, and no mechanisms of self-regulation are currently discernible. Such selfregulation was formerly enabled by powerful socioeconomic institutions constraining social and economic activity. Now, however, we are witnessing the ongoing decoupling of political power, increasingly wielded by ecologically and sociologically irresponsible forces of capital, and problems faced by human beings and by the ecosystem (Brown, 2015). The breakdown of institutions, meanwhile, includes the dismantling of institutions of democratic accountability, and is neither transformative nor adaptive (Streeck, 2016). Consequently, the minor reparative tactics currently employed and available are entirely ineffectual in tackling the major and imminent danger facing the planet's ecosystem (Klein, 2014). Significant problems exist on multiple levels of the socioecological system, and there are not tools within the system available to tackle them. This is a sign of impending irreparable systemic collapse (Obłój, 1986).

On the meso level, of particular relevance to organization studies, the interregnum presents itself 
primarily as the degeneration of work and management. Management, as practice and as a discipline, no longer concerns itself with production, but primarily with extraction: reckless depletion of natural and human commons and resources (Fleming, 2017). Management no longer strives after presenting itself as making a substantial difference or holding up important values, and economic value has been completely decoupled from its social valuation (Mazzucato, 2018). Instead, managerial effort focuses on projection of empty, false and narcissistic images, making grandiose claims without even making an attempt at making them pass as substantiated (Alvesson, 2013).

The meaninglessness of work is one of the major contradictions within the current stage of the capitalist system, destabilizing and destructive (Harvey, 2015). It poses a serious threat to human wellbeing, bringing emotional exhaustion and diminished well-being (Shantz, Alfes, and Truss, 2014).

Jobs utilize our public imagination and buzz of
life, our vested abilities and genuine desire to self-
organize, but the net payback is a momentum of
subtraction rather than freedom. Worry, fear,
anxiety, and a nagging sense of purposelessness tend
to result, or what Virno calls a lasting "not feeling at
home" (Fleming, 2014, p. 3).

Organizations have turned into "zombie-machines", killing what is human in us all, working for them, forcing upon us modes of engagement that are completely unrelated to learning or identity formation (Harding, 2013). Management nowadays is often concerned not about making work even tolerably meaningful but of about persuading people to act as if they feel that they are being alive at work, even though they are well aware of that their work fulfils no real needs (Cederström and Fleming, 2012). In the present volume, Tommy Jensen uses this background to consider the organizational consequences of this near universal depletion of meaning from work. Building on Bauman's concern with adiaphorization, or the removal from moral consideration, of human relations, Jensen analyses what happens when liquid consumers enter the roles of managers and employees. The institution of organization is in the process of being consumed from within: human bonds disappear first, making ethics as we know it devoid of contents. Organizations become adiaphoric, present themselves as being "outside of morality". The next step ahead on this road seems to mirror Jorge Luis Borges' imaginative fable of a society ruled by chance: management relinquishes control over organizational processes, even as the workers continue to be bound by these processes' outcomes. Organizational institutions, the instruments of building certainty, are left to liquefy and melt into thin air.

The degradation of meaning pertains to managers just as much as to the managed. But this is not the end of it. Management concepts and language has been colonizing contexts outside organizations, and now forms an inherent yet diffuse part of everyday life (Fleming, 2014). We have arrived at a point where management is everything (from self-branding through time management to managing one's learning) but means, in fact, nothing. With the business (sic!) of life framed as a managerial activity, sensemaking has become self-referential and adiaphoric. Societies and organizations fragment, to a point when nobody is left to see the whole picture any more: not even the manager, now part of the dissipative process of managing her or his own career. Where classical management thought (e.g. Barnard, 1938/1974) saw the manager's job as consisting of uniting and understanding the totality, its current reformulations veer towards divide et impera.

Retrotopia is a sociological journey into this bleak, fragmented world. In the place the old (often unfair and discriminatory) social institutions and mechanisms, pathologies are developing and growing to take truly dystopian measures. Humanity has not abandoned its aspirations, but it seems to have run out of faith in utopias located in the future, turning instead to the past, as if to turn back the clock which is, of course, not possible, for many reasons. Hope is placed in the past, albeit a past that had never existed, a dreamed up history without the educating capacity of experience and suffering. The past of the populist visions is nostalgic and problem-free, which means: free of all that is alien, unlike mythical "us", communities based on stark but impossible similarities. It is a past of popular television series rather than history books, one able to reunite "security with freedom" (Bauman 2017 , p. 8). The impossible project runs along several main scenarios which Bauman presents in his book: back to Hobbes and his Leviathan, back to tribes, back to inequality, and back to the womb. This is a past unreal, one that never existed but the current desire to resurrect it gives birth to very real feelings and moods: of xenophobia, racism, contempt for the poor, 
resentment for everything different": the conviction that the worsening of "our" fate is due to the fault of "them", those weaker than us. The modern state, which tries to emulate the Hobbesian Leviathan, is in for a hopeless if hostile endeavour: contemporary states are "porous, easily permeable territorial boundaries" (p. 22), a contradiction to how the Leviathan was supposed to function. Power is nowadays divorced from territory and so this attempt is doomed as pointless, yet bound to employ state sponsored violence - in order to prevent violence, taking the form of terrorism and meaningless accumulated aggression.

The answer to the dilemma is not to be found in another retrotopia - the idea of retrieving an ideal world of likeminded tribesmen (and perhaps women). The re-enactment of tribalism focuses around the long lost principle of "natural identity" and what it presents, in today's world, is a war of all against all, where everyone has the "better heritage" and wants to become "great again". This state of indefinable greatness is sought after by division, the construction of walls, by dissent. Another way back is taking us into growing inequalities. The achievements of the post-WWII years are being rolled back, one after another, in the name of recreating a more "natural" world order. This is a successful endeavour, as the world is now reaching levels of inequality from at least one century back in time. Yet no natural vitality is to be found in this project, quite the opposite, austerity is not re-invigorating world economies, it is killing them as well as numerous human beings in rich and in poor countries alike.

The human being emerging from this journey back into the illusory past is the self-obsessed narcissist. The desire to get back into the womb, the all-enfolding, absolute self, does not result in joy. Narcissism is not about real love for oneself, it is a desperate hollow search for a content that does not exist by focussing on erecting impressive facades. Everybody's mission is to create impressions on others, who are equally preoccupied with impression making and so lack both the time and the interest in the appreciation of these efforts. We have ended up in a world of surfaces reflecting off each other.

Having lost (or turned our backs on) all visions of an alternative - better - society of the future associating the future, if not with 'worse than the present' then with 'more of the same' (another increment in salary, another career promotion, another new gadget, another holiday, another shift in fashion of dress, cars, wallpapers) - no wonder that, when seeking genuinely meaningful ideas, we turn, nostalgically, to the buried (prematurely?) grand ideas of the past. We are allowed to conclude that the vision of a 'better life' has disentangled itself from its made-in-Heaven marriage to the future (p. 129).

Retrotopia is a sad portrait of contemporary society, and also a call for a common and conscious effort to put to a use all of the dimensions of engaged social reflection. This is the reading foregrounded in the present volume by Stewart Clegg's incisive examination of Retrotopia as an instance of social sciences dedicated not just to understanding the world, but to changing it. Clegg steps beyond the book to examine the patterns and structures at work in the processes of institutional dissolution, but also reflects on the engaged social role that sociological reflection needs to take on in times of regress and change: to connect ideas and observations on a larger scale than the day-to-day coping and muddling through, and to develop a perspective that may stimulate human imagination to help us out of the seemingly impossible traps.

In the fragmented world of today it is crucial that we understand the dynamics of our predicament. Bauman proposes just that in his classification of modernity into succeeding phases, leading to the current state of interregnum. The realization of both significant changes taking place over the years, and the dynamic and unstable nature of any social arrangement can help us avoid the sense of hopelessness and lack of alternatives: the all-pervasive atmosphere of powerlessness that Yiannis Gabriel (2012) labels miasma. Realization is, of course, not enough to effect meaningful change. For that, we need a collective effort aimed at radical systemic shift, coupled with responsibility and compassion enriched by sociological imagination. Bauman's book ends with this sobering advice:

There are no shortcuts leading to a quick, adroit and effortless damming of the 'back to' currents whether to Hobbes, to tribes, to inequality or to the womb. [...] We need to brace ourselves for a long period marked by more questions than answers and more problems than solutions, as well as for acting in the shadow of finely balanced chances of success and defeat. [...] More than at any other time, we human inhabitants of the Earth - are in the either/ or situation: we face joining either hands, or common graves. (Bauman, 2017, p. 166-7). 


\section{... and after?}

So where do we stand? How can we proceed from this point - in other words, how to join hands? We will now take a quick look through the Baumanian window and try to discern a possible future and means of getting from now to then. In order to do so, we will make use of one of Zygmunt Bauman's central metaphors: that of liquid modernity.

Heather Höpfl (2000) called attention to the sociological uses of metaphor as a device for understanding change, trajectories, movement of ideas. The Greek etymology of the word metaphor suggests transport or relocation, and adopting metaphoric thinking may help organizations and their members find new direction.

It is in the relationship between movement and metaphor, with the latter as the vehicle for movement or carriage, that the possibility of exploring motivation (as movement), emotion (as movement) passion (as bearing and as phoria) and expressive behaviour (as meta-phor) becomes apparent. Metaphor is about movement. (ibid., p. 26).

Metaphor can help thought reach further, be the device to expand understanding and to explore what otherwise would be inaccessible. It allows examination of the possible without resorting to reductionism, extrapolation or speculation. So, let us see where Bauman's central metaphors will take us.

The idea of liquid modernity has been criticized as not representing the physical qualities of liquids in any accurate way. However, Bauman was not particularly interested in technology or physics and that is not where he derived his notions from. He was a sociologist and a philosopher. So, in exploring the metaphor, we will consider it as an idea from the humanities and social science, and we will use some of his own musings to see where it can take us further. But because good metaphors are serve as inspiration for further thinking, we will also rely on other writings and on empirical evidence from the domain of organizations theory. Thus, we will consider liquidity as a metaphor that brings to our minds two central images: one from organizational psychology and one from Jungian symbolism.

\section{Unfreeze-change-refreeze}

The first one is linked to Kurt Lewin's (1947) famous CATS model ("changing-as-three-steps") of social change management: a three step procedure including "unfreeze-change-refreeze". Old structures need first to be "melted down", then, new ones can be introduced and the whole system re-constituted in a new shape. Change beings with the "unfreeze" stage, but it cannot end there. The liquid state of the system is but a passing stage, one necessary for the adoption of new solid qualities. A disequilibrium takes place, caused by a serious crisis. When it reaches the core of the system, undermining its beliefs, values, and assumptions, old structures start looking dysfunctional and unsustainable. This shared doubt ushers in a period of uncertainty but also of openness to new solutions and ideas. Gradually, there comes a transition from unfreezing to change and new shapes begin to crystallize. These need to be recognized and embraced as new structures before the final stage can take place: refreezing, or entering another state of solid equilibrium, one based on a new set of beliefs, values, and assumptions, better adapted to the current contexts. In this stage group participants internalize the new structure and processes of institutionalization unfold (Schein, 1996).

Following the thrust of this metaphor can help us consider questions regarding the currently dominant systemic structure and its consequences for organizations and organizing. Bauman's notions of liquidity and interregnum point towards the reading of our current predicament as the middle stage of disequilibrium, with retrotopia representing the yearning for a return to the previous state of equilibrium. Such yearnings ignore the systemic causes of present unfreezing (Bauman's own writings suggest the unchecked desire for modernisation as the main culprit) as well as the need for new values to serve as foundations for new structures. So, what shape can future after retrotopia take? Or, in the terms of the Lewinian take on Zygmunt's metaphor of liquid modernity, around which sets of values and ideas can a "re-freeze" take place?

Barbara Czarniawska, in the present volume, tackles similar questions through examining strong plots in Bauman's Retrotopia, as compared with two works of narrative fiction. Thus she extends Bauman's reasoning to three other areas: political systems, academia, and technology. She shows both the lure and the difficulties 
arising from seeking past solutions to present problems, and rejects both retrotopian and utopian approaches. Instead, Czarniawska proposes to start looking - and working - on the spot, in the present, to create bonds shared with the social actors already sharing our world: a warmth and a sense of belonging. She labels this epitopia, the goodness of here and now.

Zygmunt Bauman himself believed in democratic socialism as a general set of yardsticks for measuring up possible futures (1976/2011). He considered this a utopian ideal with little in common with the nominally socialist dictatorships of the twentieth century. Bauman's socialism is, instead, an active utopia, a living counter culture. Quoting Oscar Wilde, who famously quipped that a map of the world without utopia is not worth even a glance, Bauman argues that it is the utopians, not the realists, who are able to think up new systems and better worlds. Utopias relativize the present, engage elements of culture which have the most potential for human collective creativity, they endure throughout history. The utopia of democratic socialism is a model of society aimed at equality and common well-being. It fulfils Lewin's condition for social change: it exists as a shared imagination, even if not as a set of ready rules to be followed. It is a strong and enticing image of a possible and sustainable future: its main structural foundation is the importance of social justice and equality.

Management, in this utopian vision, takes as its aim the redistribution of wealth so that the weak and deprived are embraced in the solidarity of a communal well-being. Bauman follows here the Marxist vision of socialism following after capitalism's effort of building wealth, refocusing on shared participation in society and the fruits of its labour. Such socialism is defined primarily not as a mode of rule and administration but of activity of the masses. In a more recent book, Zygmunt Bauman agrees to a proposition by one of us (Monika Kostera in: Bauman, Bauman, Kociatkiewicz and Kostera, 2016) that cooperation, solidarity and self-management could serve as foundation of such a new system. He proposes the meso level, that of cities and organization, as a potentially fertile ground for the actualization of such ideas. Capitalism, having reached its neoliberal stage, is rapidly losing credibility, with its deficiencies becoming ever more obvious and openly discussed.
In the fourth article included in this special section, Nancy Harding proposes reconceptualizations of management that could provide us with ways leading out of the neoliberal managerialist trap. She considers the relationship between management and professions, and uses the notion of retrotopia to problematize assumptions underlying current practices and to show how new, more healthy roles and structures can be developed. Answering Bauman's call for microrevolutions, she pinpoints some instances where dialogue can be applied to achieve radical constructive change. Relating to each other in these instances may be the steppingstone towards reclaiming of meaningful work and organizational blossoming.

We are still far from being able to predict the replacement for the neoliberal modes of management, even as we can clearly pinpoint the deficiencies of the currently dominant practices. One promising line of thought (or possibly an alluring utopia?) offers the spirit of communality as the basis for more inclusive managerial practice. Currently this is still in statu nascendi, and, despite overly naïve and enthusiastic voices from proponents of irresistible technological process, neither predetermined nor a question of simple transition. However, people have a real and valid capacity for cooperation:

Corporate management does the job of choking the cooperative flame with the toxic smoke of competition and preventing the cooperative embers from bursting into flames by rendering interpersonal bonds shallow, short-term, prospect-less, frail, untrustworthy and unreliable [...] Cooperation and the instinct of workmanship are born and grow together - and together they die (or rather fall flat or into a coma - they never really die) (Zygmunt Bauman in: Bauman et. al, 2016, p. 114).

Bauman notes that this shift in management practice and thought would take a colossal effort in design, experimentation and monitoring and calls for an exploration and dissemination of instances of working examples and tools for such a system. This call can be tentatively answered by many voices of researchers dedicating their effort to the investigation of the phenomenon known as "alternative organizations", that is, organizations beyond the reductionist definition of corporate capitalism (Parker, Fournier and Reedy, 2007). Among the rich flora of publications contributing to this area, which is growing in popularity, there are more or less empirically grounded 
depictions and propositions of community based selfmanagement. For example, Erik Olin Wright (2010) offers a comprehensive map of economic organizations operating outside of the framework of the capitalist system and the various principles and structural ideas adopted by their managers and participants. Ewa BogaczWojtanowska (2013), having carried out an extensive study of Polish alternative ideas-driven organization, shows that they are able to operate smoothly thanks to an extensive and elaborate collaborative (noncompetitive) network. Martin Parker (2011) seeks inspiration in historical and fictive examples such as pirates or Robin Hood, to check which of the images can provide insights and ideas for actual contemporary organizations wishing to adopt more self-managerial philosophies. Patrick Reedy, Daniel King and Christine Coupland (2016) suggest that alternative organizations may not only offer a viable alternative to the current economic and managerial model, but also throw light on how the importance of management and organization does not rely on the current economic model, as well as showing how these concepts can be rethought while still remaining relevant to lived experience and practice. This is borne out in a prolonged ethnographic study of alternative organizations located in Poland and in the U.K., including cooperatives, value driven businesses, and anarchist collectives, carried out by one of us, begun in 2012 and still ongoing as we write this text. A recent article presenting some of the preliminary research findings (Kostera, 2018) identifies two cultural pillars working simultaneously to uphold the principles of organizing, labelled there as the archetypes of the adventurer and of the lover. The daring and bold adventurer is commonly encountered in extant stories of organizational heroes, inspiring social roles of entrepreneurs and innovators. The lover, whose feelings and commitment to other people bring and hold the organization together, is a less common protagonist of capitalist organizational stories, but no less important for meaningful organizing and meaningful work: sociality is a very strong motif in the day to day functioning of the studied organizations, as well as their strategic positions and commitments. Together with the more widespread heroic entrepreneurial spirit, an interesting hybrid of engagements is created, with a great potential for radical change

This line of thinking is presented in more general, manifesto-like terms, in George Monbiot's (2017) Out of the Wreckage. This is an inspirational text, and intended as such, proposing a broad systemic alternative for the now dead capitalism. Currently the economy, as well as the political domain, are run in a way that best can be described as a wreckage approach (a point upheld also by Peter Fleming, 2017). If we are to move beyond the point of demolition and destruction, we need a general impulse, a set of good orientation points of a new system, which can take us forward, into the future. Monbiot proposes a self-managed, community based political and economic structure, a "politics of belonging", as he terms it, very much reminiscent of both Zygmunt Bauman's visions, and of many of the alternative organizations mentioned above. A society reorganized from the bottom and up may be a utopia that has a strong and solid foundation and thus a good chance to succeed as a visionary guidance for the construction of a new, solid system, based on a different set of principles, derived from human sociality:

When we emerge from the age of loneliness and alienation, from an obsession of competition and extreme individualism, from the worship of image and celebrity and power and wealth, we will find a person waiting for us. It is a person better than we might have imagined, whose real character has been suppressed. It is the one who lives inside us, who has been there all along. (ibid., p. 185-86)

\section{Dissolution-separation-conjunction}

The second image the metaphor of liquidity brings to mind is derived from archetypical thinking, using the metaphor of alchemical operations. In Johann Daniel Mylius' (1622/2011) alchemical writings the sequence dissolution-separation-conjunction plays an important role. During dissolution a calcified element (often known as "salt") is dissolved in liquid. Separation is when more solid elements appear as an effect of dissolution, through filtering or settling. This is a stage of purification, pure and impure elements emerge and can be taken apart. Conjunction follows separation. Selected separated elements are brought together and form a new substance. This stage is a moment of resolution and revelation, the beginning of new insights and modes of being. Alchemical imagery and ideas have been and continue to be culturally significant, even as the practice of alchemy receded to the realm of pseudoor proto-science. Carl Gustav Jung (1968/1980) used alchemical images to elucidate psychological 
and spiritual phenomena, such as transformation and individuation. In his work, the alchemical process is depicted as a path towards transcendence and renewal, integration of hidden and unconscious elements, a possibility of a higher synthesis of what has been playing a contradictory role. Alchemical symbolism helps to make conscious and understand deep processes involving the transformation of forms which serve as incarnations of the soul, that is, both body and mind, without imposing upon them the dualism, otherwise prominent in Western visualisations of psychological phenomena. Jungian symbolism has also been used in organization studies (see e.g. Gabriel, 1999b; Moxnes, 1999) to depict patterns of unconscious dynamics of culture creation, such as deep roles, archetypes and modes of organizational change.

The alchemical metaphor also proposes an interesting narrative thrust with regard to possible developments after the liquid modern phase of society. The emerging structurizations do not have to form a complete systemic picture, not yet, but they may develop into new potentialities not by what we used to recognize as consistent processes of social construction, but by novel and perhaps even unforeseen synergies. We do not aspire to make a complete list of those, just to present a few, the traces of which can be found in Zygmunt Bauman's thinking. If liquid modernity is its various aspects represents the alchemical operation of dissolution, then, what follows, is the separation of new elements. This is the image of current stage of society, the interregnum, when old patterns and institutions fall apart and cease working as connected wholes. The increasing fragmentation brings into focus a number of attitudes, position and practices which strike as unconnected with each other, disintegrated and even broken. The solution of this state of things is currently usually sought in the illusory past, when "things used to work". But, when considered for what they are, in their potentiality, they can enlighten us with regards to possible future transformations. As we have proposed in the preceding fragment, sociality is one such attribute of the human condition which is becoming visible for some of the observers of society, as a source of hope and promise for the future. We take it to be one of the key products of the separation. Other elements with similar potential, which we will consider are: dialogue, art and imagination.
Dialogue is what Bauman himself posits as an approach that may offer a way out of the current crises of the interregnum, but only if taken seriously, as a systematic approach accompanied by inclusivity and sociality. Quoting pope Francis, Bauman insists that dialogue should become an integral part of our culture, to be taught in schools and integrated in all organized endeavours. Both Nancy Harding and Stewart Clegg develop this idea in their texts.

Bauman emphasizes that his call for the centrality of dialogue is directed at all humanity, not just the professionals or the politicians. Dialogue and sociality are what can bring us a fate of peace and hope of integration. Dialogue is part and parcel of who we are as human beings but what needs to be done is to recognize each other as "valid dialogue partners". It will not be a harmonious choir, rather, a difficult time, a "period marked by more questions than answers and more problems than solutions" (Bauman, 2017, p. 167). The propensity for such a dialogue springs from the very basic human impulse for compassion, interaction with the Other.

Dialogue is, of course, present in our current social practices, but only in a limited and stunted form. It is applied only to constrained constructs such as neighbourhoods, significant relationships, more or less imaginary tribes. But the human predisposition towards dialogue is visible and perhaps increasingly obvious, and thus possible material for institutionalization, possibly following Mikhail Bakhtin's blueprints for the dialogic imagination (1981).

Dialogue does not, of course, offer a solution to our current problems, as the contemporary retrotopian tendencies to move "back to tribes" are showing. But taken together with sociality and inclusivity dialogue can help to achieve a new level of understanding, necessary for finding new solutions and the creation and spreading of new organizational forms. The abovementioned field research in alternative economic organizations suggests that whenever this conjunction is working, sustainable and democratic, even if not "fast", modes of decision making and involvement occur and are turned into patterns of organizational action by the participants (Kostera, 2014; 2017). The operation of these organizations is often based on intensive and prolonged dialogue as one of the key principles of how the organization is managed. Application varies 
from full immersive and direct democracy to regular consultations. Studies and accounts of new social movements show similar insights (Hytten, 2016; Solnit, 2006), even when they use different terminology to describe them.

Leadership is always collective, at very least shared by two persons, more typically cooperative, rotational or group based. Much time and energy is dedicated to face to face meetings, discussions and outreach. Some organizations try to involve stakeholders in their dialogues, and there are also attempts at forming dialogic networks between similar organizations of a regional and national reach.

The second product of the current separation that has interesting potential for future organizational constructions is art: the human inclination to create art, but also the art of life itself. Zygmunt Bauman points to the instrinsic value of contentment, rather that happiness, the latter being much overrated, and throughout the liquid phase of modernity posing as an unfulfillable promise, an endless desire (Bauman, 2008). Contentment is a different state of mind, a resolution and intense satisfaction, such as, for example, the feeling of "gratification of work well done for the sake of leaving the world - the humans' shared abode - in just a little bit better (and above all not worse) condition that one [found] it on entry" (Zygmunt Bauman in: Michael Hviid Jacobsen, 2013/2016, p. 26). But there is also a profound human happiness, which is not about the pursuit of things or products to consume, one which is an art in itself. Bauman cites Pascal, pointing to the source of unhappiness as the inability to be quiet in a room, the rejection of silence and solitude (ibid., p. 3637). Life is a work of art because it is its intrinsic value: "the life of a being endowed with will and freedom of choice" (p. 53). The art of life is a genre, the most widely practices one, of art as a broader category, including the fine arts. The two belong together:

As in so many other respects, so in this case, the fine arts replicate life; in most cases, new currents in the fine arts follow, with some delay, changes in the mode of life - and sometimes succeed in inspiring or facilitating a change and smoothing its entry into the practices of daily life (p. 73).

But the opposite is true as well: art is a teacher of life (Zygmunt Bauman in: Zeidler-Janiszewska, 1997, p. 119). They both spring from the same need: of leaving a trace of good work in the world, adding something good to it, but also creating an identity, for an individual, group or social class (Bauman, 2013b). However, taken separately, all by itself, the human propensity for art (including art of life), does not necessarily bring new cultural impulses for a better society. In the era of the interregnum it is often being practiced in a retrotopian manner, as a journey "back to the womb", or the relentless self-seeking of current times (Bauman, 2017). It has also been the subject of a process of liquefaction: mainstream art has become a disposable product, relegated to modes of inattentive consumption (Bauman, 2007). To serve more societally constructive purposes, it has to be used in the conjunction with sociality. Zygmunt Bauman himself points into that direction - art can be an inspiration for communities to create an identity, a sense of belonging, if it is practised together, in an integrative manner, not as (yet another) means of self-assertion (Bauman, 2008). Art philosopher Anna Zeidler-Janiszewska (2011) examines the community creating potential of art, building upon the work of, among others, Zygmunt Bauman. She argues that art has the unique capability of creating a collective identity which is not by definition antagonistic, or defined in opposition to another group or community, which tends to be the dominating mode of collective identity construction. It is not a quality of art as such, but a special use of art, a way of meeting others, which is non-dualistic and which can be based on the seeking out of similarities. It is not a market driven art, not an egalitarian art, or an art based on consumption, but an inclusive art, both old and new, avant garde and mundane, can offer a kind of a common language, enabling the crossing of borders and barriers. Narrative identity has its limitations, but art can help to create an identity based on a unifying spirit, a culture able to live with difference.

Organization theorist Stevphen Shukaitis (2016) presents an overview of how art, aesthetics and activism inform one another and how they inspire new, radical forms of organizing. A number of examples: from the Situationists to Laibach, offer insights into the different practices of labour, resistance and emerging ideas of governance beyond managerialism and capitalism. Radical art has the capacity to facilitate social movements, help with communicating novel ideas and create a collective composition: a belonging extending beyond mere aesthetic success. Art becomes incorporated into social life and helps to share strategies, 
as well as an encompassing "expressive ontology of labor" (p. 15), not only providing alternatives organizers with a language to use for the communication of nonalienated work, but also with a destabilizing potential, a message sent out to people in the mainstream capitalist economy to resist and refuse alienated work. Radical art can mobilize labour's autonomy within the failing capitalist system.

The third product of separation we would like to briefly consider is imagination. It is mainly emerging as a lack, a deficit of contemporary times, visible by its absence Bauman (2011) argues that the lack of imagination fuels current moral deficit. Without imagination, society is confined to seeking technical solutions, leaving no space for leaving one's self-centred perspective and opening up for the consequences proposed solutions may have for others. Where there is no imagination, there is no empathy, and without empathy ethics is just another set of oppressive rules. Furthermore, modern evil is the result of the separation of imagination and creation. Humans act, zombie-like, without the compass of moral truth, which can be offered only by imagination.

The reality grasped by perception orphaned by imagination, and beyond which it is unable to reach is always read-made, technologically prefabricated and operated; there is no room in it for those thousands or millions cast at its receiving end and sentenced to destruction by atomic bombs, napalm or poisonous gas. That reality consists of keyboards and pushbuttons. (ibid., p. 147).

A number of other authors, including David Graeber (2015), Peter Fleming (2015) and David Harvey (2015) commenting on the problems we are facing due to the colonization of society by neoliberalism expresses a similar view: we badly need imagination these days, the path of liberation from late capitalism necessarily leads through the liberation of imagination. To Graeber (2015) imagination is the ultimately human faculty, the source of all real value, which can help us to being new things and organizational forms to being. Fleming (2015) upholds that a worker's historical (and sociological) imagination is capitalism's worst enemy, as the eye begins to see through memory and the coded can be decoded, and new dreams can be dreamed. Harvey (2015) sees a ray of hope in imaginative possibilities of society and the economy to create a new egalitarian and democratic system; the colonized should use their imagination to get rid of the colonist. It is, to him, a radical humanistic project.

There are notable empirical examples which can offer hope: in alternative movements and organizations imagination (both individual and collective) serves as the basis for how strategic and visionary work. Some organizations have dedicated spaces, structures and rituals dedicated to promoting this kind of work, such as games or brainstorming meetings. Others rely on spontaneous outbursts of imagination in a setting that meets resultant insights with respect.

However, imagination as such does not help: most of contemporary retrotopian flights are, in fact, flights of fancy. According to Karl Weick fancy is a flawed, underdeveloped imaginative ability, when associations are created by adjacency: sets of formerly existing elements put together into a new whole. Imagination is the work using compound associations of simultaneity, in other words, "imagination gives form to unknown things" (Weick, 2006, p. 447). Fancy modifies, but imagination both modifies and shapes anew. It allows ideas to grow exponentially, as if by own force. Perhaps, using the alchemical metaphor, imagination has not yet become sufficiently separated out in the process of dissolution. We need more societal, political, economic and academic focus on imagination,

In conjunction with sociality, imagination gives power to the moral impulse, as Bauman (2011) argues, allowing not only to engage in meaningful relationships but to actively resist the liquid modern leading organizing principle: adiaphorization (Bauman and Donskis, 2013). Imagination and sociality can help us to think up a story for our times, in which there would be both power to inspire, and to draw us near to each other and thus save us from despair, the state

we fall into when our imagination fails. When we have no stories that describe the present and guide the future, hope evaporates. Political failures is, in essence, a failure of imagination. (Monbiot, 2017, p. 6)

\section{References}

\author{
Alvesson, Mats (2013) The Triumph of Emptiness: \\ consumption, higher education, and work \\ organization. Oxford: Oxford University Press.
}


Barnard, Chester (1938/1974) The Functions of the Executive. Cambridge: Harvard University Press.

Bauman, Zygmunt (1976/2011) Socialism: The active utopia. Oxon: Routledge.

Bauman, Zygmunt (1993) Postmodern Ethics. Cambridge, MA: Basil Blackwell.

Bauman, Zygmunt (2008) The Art of Life. London: Polity Press.

Bauman, Zygmunt (2011) Collateral Damage: Social inequalities in a global age. Cambridge: Polity Press.

Bauman, Zygmunt (2012) "Times of Interregnum", Ethics and Global Politics, 5(1): 49-56.

Bauman, Zygmunt (2013a) Does the Richness of the Few Benefit Us All? Cambridge: Polity Press.

Bauman, Zygmunt (2013b) Culture in a Liquid Modern World. Cambridge: Polity Press.

Bauman, Zygmunt (2007) "Liquid arts", Theory and Society, 24(1): 117-126.

Bauman, Zygmunt (2017) Retrotopia. London: Polity Press.

Bauman, Zygmunt, Irena Bauman, Jerzy Kociatkiewicz, and Monika Kostera (2015) Management in a Liquid Modern World. Cambridge: Polity Press.

Bauman, Zygmunt and Leonidas Donskis (2013) Moral Blindness: The loss of sensitivity in liquid modernity. Cambridge: Polity Press.

Berger, Peter L. and Thomas Luckmann (1966/1991) The Social Construction of Reality: A treatise in the sociology of knowledge. London: Penguin.

Bogacz-Wojtanowska, Ewa (2013) Zdolności Organizacyjne a Wspótdziatanie Organizacji Pozarządowych. Kraków: ISP UJ.

Brown, Wendy (2015) Undoing the Demos: Neoliberalism's stealth revolution. Cambridge, MA: Zone Books.

Burrell, Gibson (1997) Pandemonium: Towards a retro-organization theory. London: SAGE.

Cederström, Carl and Peter Fleming (2012) Dead Man Working. Winchester: Zero Books.
Clegg, Stewart R. (forthcoming) "Liquefying modernity and organization studies", Organization Studies, forthcoming.

Clegg, Stewart R. (2006) "Why Is Organization Theory so Ignorant? The neglect of total institutions", Journal of Management Inquiry, 15(4): 426-430.

Fleming, Peter (2014) Resisting Work: The corporatization of life and its discontents. Philadelphia: Temple University Press.

Fleming, Peter (2015) The Mythology of Work: How capitalism persists despite itself. London: Pluto Press.

Fleming, Peter (2017) The Death of Homo Economicus: Work, debt and the myth of endless accumulation. London: Pluto Press.

Gabriel, Yiannis (1999a) "Management, Administration and Critique in the 21st Century?" Administrative Theory \& Praxis 21(4): 402-408.

Gabriel, Yiannis (1999b) (ed.) Organizations on Depth: The psychoanalysis of organization. London: SAGE.

Gabriel, Yiannis (2012) "Organizations in a State of Darkness: Towards a theory of organizational miasma", Organization Studies, 33(9): $1137-$ 1162.

Graeber, David (2015) The Utopia of Rules: On technology, stupidity and the secret joys of bureaucracy. Brooklyn: Melville House.

Gramsci, Antonio (1971) Selections from the Prison Notebooks. London: Lawrence \& Wishart.

Harding, Nancy (2013) On Being at Work: The social construction of the employee. New York: Routledge.

Harvey, David (2015) Seventeen Contradictions and the End of Capitalism. London: Profile Books.

Höpfl, Heather (2000) "On being moved" Studies in Cultures, Organizations and Societies, 6(1): 15-34.

Hytten, Kathy (2016) "Globalisation, democracy, and social movements: The educational potential of 
activism", Educational Philosophy and Theory, 48(10): 981-996.

Jacobsen, Michael Hviid (2013/2016) in: Mark David (ed.) Liquid Sociology: Metaphor in Zygmunt Bauman's analysis of modernity. London: Routledge, pp. 13-26.

Jermier, John M. and Stewart R. Clegg (1994) "Critical Issues in Organization Science: A dialogue”, Organization Science, 5(1): 1-13.

Jung, Carl Gustav (1968/1980) Psychology and Alchemy, Collected Works of C. G. Jung, London: Routledge.

Kelemen, Mihaela and Tuomo Peltonen (2001) "Ethics, Morality and the Subject: The contribution of Zygmunt Bauman and Michel Foucault to 'postmodern' business ethics", Scandinavian Journal of Management, 17(2): 151-66.

Klein, Naomi (2014) This Changes Everything: Capitalism vs, the climate. New York: Simon and Schuster.

Kociatkiewicz, Jerzy and Monika Kostera (2014a) (eds) Liquid Organization: Zygmunt Bauman and organization theory. Oxford: Routledge.

Kociatkiewicz, Jerzy and Monika Kostera (2014b) "Towards sociological compassion: An introduction", in: Jerzy Kociatkiewicz and Monika Kostera (2014a), pp. 1-12.

Kostera, Monika (2014) Occupy Managament! Ideas and inspirations for self-management and selforganization. Oxon: Routledge.

Kostera, Monika (2017) “Adventurers and Lovers: Organizational heroines and heroes for a new time", Journal of Genius and Eminence, 2(2): 115-125.

Kuczyński, Piotr (2011) Lawnswood Gardens. Film published by Delos Films.

Lévinas, Emmanuel (1999) Totality and Infinity: An essay on exteriority. Pittsburgh: Duquesne University Press.

Lewin, Kurt (1947) "Group decision and social change", in: Theodore M. Newcomb and Eugene
L. Hartley (eds) Readings in Social Psychology.

New York: Henry Holt, pp. 330-344.

Mazzucato, Mariana (2018) The Value of Everything. London: Allen Lane.

Mills, Charles Wright (1959) The Sociological Imagination. London: Oxford University Press.

Monbiot, George (2017) Out of the Wreckage: A new politics for an age of crisis. London: Verso.

Moxnes, Paul (1999) "Deep roles: Twelve primordial roles of mind and organization", Human Relations, 52(11): 1427-1444.

Mylius, Johann Daniel (1622/2011) Rosarium Philosophorum: Of the De Alchemia Opuscula. Calgary: Theophania Publishing.

Obłój, Krzysztof (1986) Zarządzanie: Ujęcie praktyczne. Warszawa: PWE.

Parker, Martin (2011) Alternative Business: Outlaws, crime and culture. Oxford: Routledge.

Parker, Martin, Valerie Fournier and Patrick Reedy (2007) The Dictionary of Alternatives. London: Zed Books.

Reedy, Patrick, Daniel King and Christne Coupland, C. (2016) "Organizing for individuation: Alternative organizing, politics and new identities", Organization Studies, 37(11), p. 15531573.

Schein, Edgar H. (1996) “Kurt Lewin’s change theory in the field and in the classroom: Notes toward a model of managed learning", Systems Practice, 9(1): 27-47.

Shantz, A., Alfes, K., and Truss, C. (2001) "Alienation from work: Marxist ideologies and twenty-firstcentury practice", The International Journal of Human Resource Management, 25: 2529-2550.

Shukaitis, Stevphen (2016) The Composition of Movements to Come: Aesthetics and cultural labour after the avant-garde. London: RowmanLittlefield.

Solnit, Rebecca (2006) Hope in the Dark: Untold histories, wild possibilities. New York: Nation Books. 
Streeck, Wolfgang (2016) How Will Capitalism End? Essays on a failing system. London: Verso.

Ten Bos, Rene (1997) "Business ethics and Bauman ethics”, Organization Studies, 18(6): 997-1014.

Weick, Karl E. (2006) "The Role of Imagination in the Organizing of Knowledge", European Journal of Information Systems, 15(5): 446-452.

Wright, Erik Olin (2010) Envisioning Real Utopias. London: Verso.

Zeidler-Janiszewska, Anna (1997) (ed.) O Szansach i Putapkach Ponowoczesnego Świata. Warszawa: Instytut Kultury.

Zeidler-Janiszewska, Anna (2011) “Od jednoczącego ducha do (nie)tożsamości kulturowej mieszkańców Europy”, Kultura Wspótczesna, 5: 199-216. 